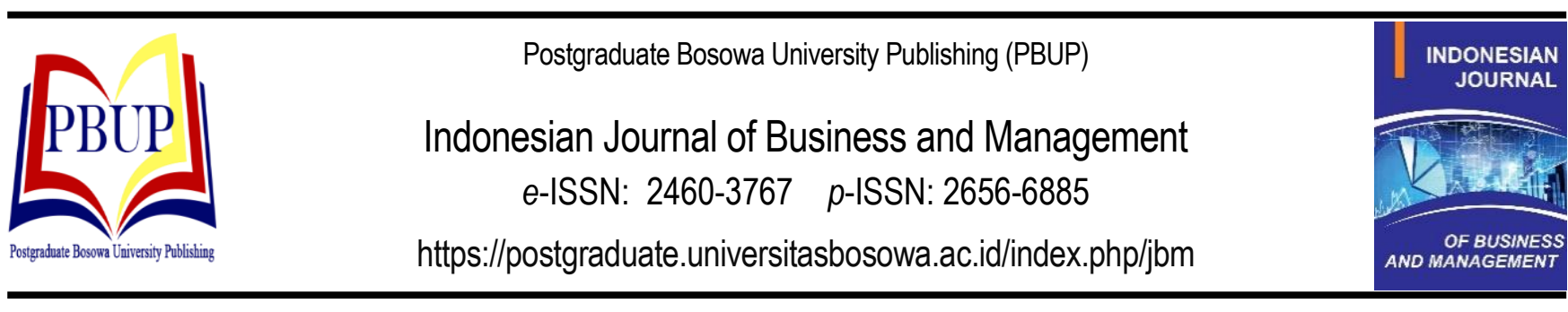

\title{
PENGARUH SALURAN DISTRIBUSI, BIAYA PEMASARAN DAN VOLUME PENJUALAN TERHADAP PENDAPATAN PETANI KENTANG DI KABUPATEN GOWA SULAWESI SELATAN
}

\author{
The Effect of Distribution Channel, Marketing Cost and Selling Capacity on the Income \\ of Potato Farmers in Gowa South Sulawesi
}

\author{
Arnas Hasanuddin ${ }^{1}$, Miah Said ${ }^{2}$, Muhlis Ruslan ${ }^{2}$ \\ ${ }^{1}$ Mahasiswa Magister Manajemen Universitas Universitas Bosowa \\ ${ }^{2}$ Program Studi Manajemen Program Pascasarjana Universitas Bosowa
}

Email: arnashasanuddin@yahoo.com

Diterima: 22 Agustus 2020/Disetujui: 05 Desember 2020

\begin{abstract}
ABSTRAK
Penelitian ini bertujuan untuk mengetahui berapa besar pengaruh variable saluran distribusi (X1), biaya pemasaran (X2) dan volume penjulan (X3) terhadap pendapatan petani kentan (Y). Dan tujuan berikutnya adalah untuk mengetahui saluran distribusi pemasaran yang paling efisien dari petani hingga ke konsumen akhir. Metode penelitian yang digunakan adalah metode survey dengan menggunakan 143 responden petani kentan yang ada dilokasi peneklitian. Hasil penelitian menunjukkan bahwa variable biaya pemasaran (X2) kurang berpengaruh terhadap tingkat pendapatan petani kentan sedangkan hipotesi yang dikemukakan berpengaruh. Adanya temuan yang berbeda dengan hasil uji statika (uji t), dimana biaya pemasaran kurang berpengaruh dibanding variable X1 dan X3, karena pedagang perantara langsung ke lokasi petani sehingga kurang mengeluarkan biaya pemasaran dan secara lagsung mempengaruhi tingkat pedapatan petani. Saluran distribusi yang paling efisien berdasarkan uji formulasi efsiensi pemasaran adalah pada saluran pemasaran yang IV ( dari produsen- pedagang perantara- konsumen $=21,39$ ). Teknik pengambilan sampel menggunakan teknik simple jenuh. Hasil penelitian menunjukan bahwa saluran pemasaran merupakan variable dominan yang mempengaruhi tingkat pedapatan petani kentan di Kecamatan Tombolo Pao sebesar 0,586 dan disusul pada variable volume penjualan sebesar 0,249.
\end{abstract}

Kata Kunci: Efisiensi Pemasaran, Pendapatan Usaha, Petani Kentang

\section{ABSTRACT}

This study aims to determine how much the influence of the distribution channel variable (X1), marketing costs (X2) and sales volume $(X 3)$ on the income of potato farmers $(Y)$. The next goal is to find out the most efficient marketing distribution channel from farmers to the consumers. The research method used was a survey method using 143 respondents of potato farmers who were in the research location. The results show that the marketing cost variable (X2) has less effect on the income level of potato farmers, while the hypothesis stated it has an effect. There are findings that are different from the results of the statistical test ( $t$ test), where marketing costs are less influential than variables X1 and X3, because the intermediary traders go directly to the location of the farmers so that they spend less marketing costs and directly affect the level of farmers' income. The most efficient distribution channel based on the marketing efficiency formulation test is the IV marketing channel (from producer-trader to intermediary-consumer $=21.39$ ). The sampling technique uses saturated simple technique. The results showed that the marketing channel is the dominant variable that affects the income level of potato farmers in the District of Tapio Pao by 0.586 and followed by the variable sales volume of 0.249.

Keywords: Marketing Efficiency, Business Income, Potato Farmers 


\section{PENDAHULUAN}

Strategi pembangunan pertanian jangka panjang bertujuan untuk mewujudkan pertanian yang tangguh, maju, dan efisien, mengingat sampai saat ini sebagian besar masyarakat Indonesia berusaha di sektor pertanian. Salah satu prioritas yang dilakukan untuk mencapai tujuan tersebut adalah usaha pengembangan komoditas hortikultura. Prospek pengembangan komoditas hortikultura masih sangat terbuka, karena Indonesia masih memiliki banyak lahan yang belum termanfaatkan secara optimal. Pada tingkat mikro, usaha ini berperan sebagai sumber penghasilan, wadah bagi calon wirausahawan, serta pengembangan daya saing individu, sedangkan di tingkat makro berperan dalam penyerapan tenaga kerja, berkontribusi terhadap pembangunan wilayah, serta sebagai pereduksi terhadap kesenjangan (Sumardjo dkk, 2002). Kabupaten Gowa Propinsi Sulawesi Selatan merupakan salah satu kabupaten yang sangat potensial untuk pengembangan komoditas hortikultura terutama sayuran karena memiliki lahan yang masih sangat luas dan iklim yang sangat cocok untuk sayur-sayuran tertentu seperti kentan, buncis, kubis dan Wortel dll.

Uraian diatas menjelaskan bahwa proses pemasaran komoditas pertanian terutama hortikultura adalah suatu proses dan rumit dan sangat kompleks. Proses pemasaran dituntut harus dapat mempertemukan kepentingan dan kebutuhan produsen dan konsumen, yang kadangkala amat saling bertentangan. Sistem pemasaran dituntut dapat mengalirkan barang/jasa ke tangan konsumen akhir secara efektif dan efisien, serta dapat melancarkan arus informasi timbal balik sebagai dasar pengambilan keputusan oleh pelaku terkait. Oleh karena itu studi dan analisis mengenai pemasaran memegang peranan yang sangat penting dalam pengembangan usaha agribisnis sayuran.

Suatu saluran pemasaran dikatakan efisien apabila sistem pemasaran tersebut mampu menyampaikan hasil (produk) dari produsen ke konsumen dengan biaya yang semurah-murahnya dan mampu mengadakan pembagian yang adil kepada semua pihak yang ikut terlibat dalam kegiatan produksi dan saluran pemasaran produk tersebut. Lembaga pemasaran biasanya terdiri dari produsen, tengkulak, pedagang pengumpul, eksportir, importir atau lainnya menjadi sangat penting. Lembaga pemasaran ini, khususnya bagi negara berkembang, yang dicirikan lemahnya pemasaran hasil pertanian akan menentukan mekanisme pasar. Bila mekanisme pemasaran berjalan dengan baik, maka semua pihak yang terlibat akan diuntungkan (Soekartawi, 2003). Situasi ini memberikan pemahaman kepada kita betapa pentingnya mengetahui alur pemasaran atau istilahnya 'rantai pemasaran' (supply chain) termasuk rencana programnya (Nonci, dkk 2019). Oleh karena itu perlu dilakukan penelitian mengenai rantai - rantai pemasaran buah kentang di Kecamatan Tombolo Pao Kabupaten Gowa. Diharapkan pada penelitian ini dapat diketahui secara langsung faktorfaktor apa yang mempengaruhi tingkat pendapatan petani kentang hubungannya aspek saluran pemasaran dari Kecamatan Tombolo Pao ke Kota Makassar.

Tingkat kapasitsa produksi buah kentang di Desa Kanreapia dipengeraruhi oleh cuaca dan hama penyakit serta kemampuan sumber daya yang dimiliki para petani antara lain modal usaha, keterampilan dan pengalaman tanam wortel, sehingga sampai saat ini luas area termanfaatkan untuk tanaman kentang baru mencapai 12,33 ha dengan kapasitas produksi rata-rata 2,10 ton/ha setiap pasca panen dari 67,23 ton yang sesungguhnya ( sumber Dinas Statistik Kabupaten Gowa Tahun 2019 dalam angka).Tanaman hortikulutura khususnya buah kentang merupakan bagian dari sektor pertanian yang mencakupi beberapa jenis tanaman seperti; tanaman wortel, kentang, ubi-ubian, bayam, bawang daun, koll dan lainnya baik sebagai bahan konsumsi masyarakat maupun untuk industri pengolahan dengan nilai ekonomi yang lebih tinggi. Dari beberapa jenis tanaman tersebut sangat potensi untuk dilakukan suatu usaha agribisnis sebagai salah satu alternative untuk diolah menjadi makanan yang beraneka ragam dan rasa melalui pengolahan, seperti makanan rebusan, kripik atau makanan gorengan. Selain itu, juga bermanfaat sebagai food terafi bagi penderita diabetes, perawatan kecantikan maupun pengobatan lainnya ( Pitojo, Tahun 2004). Adanya beberapa manfaat komoditi dari tanaman holtikultura ini, tentunya mempunyai prospek untuk diusahakan dalam bidang agribisnis dan menjanjikan keuntungan jika dikelola secara optimal dan professional. Contoh hitungan sederhana adalah, jika produksi 30 ton/ha kemtang (ratarata produksi di Negara maju) dengan harga di tingkat petani sebesar Rp. $4.500 / \mathrm{kg}$, maka diperoleh omzet sebanyak Rp.130,95 juta juta/ha/musim. Namun di Indonesia produktivitas wortel secara nasional rata-rata 10 ton/ha dari potensi hasil yang bisa dicapai 42 ton/ha ( Direktorat Perbenihan Hortikultura, Tahun 2017).

Distribusi merupakan sekumpulan organisasi yang membuat sebuah proses kegiatan penyaluran suatu barang atau jasa siap untuk dipakai atau konsumsi oleh para konsumen (pembeli). Istilah distribusi menurut Zylstra (2006) adalah suatu sistem yang menunjukkan segala sesuatu/sumber daya-sumber daya organisasi yang disimpan dalam antisipasinya disebut dengan istilah distribusi. Tetapi kita seharusnya tidak membatasi pengertian distribusi tidak hanya itu saja. Banyak organisasi perusahan menyimpan jenis-jenis distribusi lain seperti : uang, ruang fisik buka tutup, bangunan pabrik, peralatan dan tenaga kerja untuk memenuhi permintaan produk dan jasa (Reny at.al, 2019).

Distribusi adalah proses menyalurkan barang dan jasa dari produsen kepada target konsumen. Dari saluran distribusi untuk consumer product market, perantara yang langsung berhubungan dengan konsumen adalah retailer atau pengecer. Definisi ini dikemukakan oleh Oparilova (2009:22). Distribusi yang efektif akan memperlancar arus atau akses barang sehingga konsumen dapat diperoleh kemudahan untuk memperoleh produknya. Disamping itu konsumen juga akan dapat memperoleh produk yang diinginkan sesuai dengan waktu yang 
diperlukan. Produsen dan konsumen mempunyai kesenjangan, waktu, nilai, keragaman, dan kepemilikan produk karena perbedaan tujuan serta presepsi masingmasing. Dengan dsitribusi yang efektif dan efisien perusahaan dapat mengatasi kesenjangan antara produsen dan konsumen. Kegiatan distribusi sangat berpengaruh dan bergantung pada quantity atau jumlah barang yang terdapat di gudang. Karena jika quantity yang dimiliki oleh warehouse tidak mencukupi atau kurang dari jumlah order, maka proses penyaluran barang bisa berjalan lebih dari sekali sehingga menambah beban biaya penyaluran atau bisa juga sisa pengiriman yang belum terkirim dibatalkan. Meski semua itu bergantung pada kesepakatan antara produsen dan konsumen namun tetap saja akan memberikan dampak buruk bagi perusahaan.

Dalam hubungan uraian itu, Dewan Manajemen Distribusi Fisik Nasional mendefinisikan distribusi fisik sebagai berikut : "suatu rangkaian aktivitas yang luas mengenai pemindahan barangdan jadi secara efisien dari akhir batas produksi ke para konsumen, serta di dalam beberapa hal mencakup proses pemindahan bahan mentah dari suatu pembekal ke awal batas produksi”. Manajemen distribusi fisik hanyalah satu diantara istilah deksriptif yang digunakan untuk menggambarkan suatu pengendalian atas pemindahan barang seperti didefinisikan diatas.

Dalam banyak kenyataan sering dijumpai adanya kelemahan dalam mengembangkan produk-produk pertanian khususnya tanaman hortikultura disebabkan karena kurangnya perhatian terhadap masalah pemasaran. Manurut Mubyarto (1990), pemasaran merupakan suatu macam kegiatan ekonomi yang berfungsi membawa atau menyampaikan barang dari produsen ke konsumen akhir. Selain itu Downey dan Erickson (1994), menyatakan bahwa pemasaran adalah proses yang mengakibatkan aliran produk melalui suatu system dari produsen ke konsumen. Pada dasarnya pengertian tentang pemasaran adalah sebagai penghubung antara produsen dengan konsumen dimana kedua kepentingan dapat dipertemukan. Kepentingan produsen untuk menjual produk-produk yang telah dihasilkan dan kepentingan konsumen untuk memiliki produk-produk tersebut guna memuaskan atau memenuhi kebutuhan kebutuhannya.

Saluran pemasaran dapat berbentuk secara sederhana dan dapat pula rumit, hal ini tergantung dari macam komoditi, lembaga pemasaran dan system pasar. Sistem pasar yang monopoli mempunyai saluran pemasaran yang relative sederhana dibandingkandengan system pasar yang lain, demikian juga dengan komoditi pertanian yang lebih cepat tiba ke tangan konsumen dan yang tidak mempunyai nilai ekonomi yang tinggi, biasanya mempunyai saluran pemasaran yang relative sederhana. Pergerakan barang dari produsen ke konsumen merupakan jasa dari pada lembaga-lembaga pemasaran yang terlibat didalamnya. Dengan demikian lembagalembaga pemasaran merupakan badan-badan perantara, yang merupakan saluran-saluran arus pergerakan dari barang yang diperdagangkan. Seperti yang dikemukakan oleh Nurland (1986), bahwa lembaga pemasaran merupakan badan-badan yang menyelanggarakan kegiatan pemasaran, menyalurkan barang dan jasa dari produsen ke konsumen

Komoditi pertanian pada komoditas hortikultura yang nilainya tinggi diikuti dengan biaya pemasaran yang tinggi pula. Peraturan pemasaran disuatu daerah juga kadang-kadang berbeda satu sama lain, begitu pula macam lembaga pemasaran dan efektifitas pemasaran yang mereka lakukan. Makin efektif pemasaran yang dilakukan makin kecil biaya pemasaran yang mereka keluarkan.

\section{METODE}

Pendekatan dalam penelitian ini menggunakan metode penelitian deskriptif kuantitatif, dengan metode survey yaitu penelitian dengan mengambil sampel dari populasi dengan instrument koesioner, wawancara dan observasi dalam pengumpulan data. Adapun jenis dan sumber data yang digunakan dalam penelitian ini adalah meliputi; (1) data kualitatif adalah data yang diperoleh melalui keterangan-keterangan secara tertulis yang diberikan pada kantor Dinas Statisti dan Dinas Pertanian dan Tanaman Pangan Kabupaten Gowa, (2) data kuantitatif adalah berupa angka-angka yang dapat dihitung berkaitan dengan permasalahan penelitian.

Penelitian ini menggunakan pendekatan deskriftif kualitatif, dan dilanjutkan analisis data untuk menguji hipotesis melalui pengolahan data penelitian dengan menggunakan metode analisi sebagai berikut:

1. Analisis Marjin Pemasaran dengan rumus :

$$
\begin{aligned}
& \mathrm{M}=\mathrm{Hp} \text { - Hb, dimana; } \\
& \mathrm{M}=\text { Marjin pemasaran } \\
& \mathrm{Hp} \text { = harga penjualan } \\
& \mathrm{Hb}=\text { harga pembelian }
\end{aligned}
$$

Selanjutnya marjin total adalah marjin-marjin dari setiap lembaga pemasaran/pedagang perantara yang terlibat dalam penyaluran pemasaran buah kentang, dapat dihitung dengan rumus:

$$
\begin{aligned}
& \mathrm{Mt}=\mathrm{M} 1+\mathrm{M} 2+\mathrm{M} 3+\ldots \ldots \ldots \ldots . . . \mathrm{Mn} \text {, dimana: } \\
& \mathrm{M}=\text { marjin total } \\
& \mathrm{M} 1 \ldots \mathrm{Mn}=\text { marjin lembaga pemasaran yang } \\
& \quad \text { terlibat }
\end{aligned}
$$

2. Keuntungan Lembaga Pemasaran/Pedagang

Perantara dengan rumus:

$\Pi=\operatorname{Tr} \quad-\quad \mathrm{Tc}$, dimana;

$\Pi=$ Keuntungan dari setiap lembaga pemasaran

$\operatorname{Tr}=$ Total revenue

$\mathrm{Tc}=$ Total cost

3. Pada analisis efisiensi pemasaran ini, merupakan pendekatan yang menilai secara rasio dari total biaya pemasaran yang ditimbulkan oleh kegiatan fungsi-fungsi pemasaran setiap lembaga pemasaran yang terlibat.

4. Analisis Hubunya Variabel ; saluran pemasaran, biaya dan volume penjualan terhadap marjin 
pemasaran dengan menggunakan regresi berganda dengan rumus:

$\mathrm{Y}=\mathrm{a}+\mathrm{b} 1 \mathrm{X} 1+\mathrm{b} 2 \mathrm{X} 2+\mathrm{b} 3 \mathrm{X} 3+\ldots \ldots \ldots$... $n$ Xn, dimana :

$\mathrm{Y}=$ marjin pemasaran

$\mathrm{a}=$ konstante

bn $=$ koefisien regresi

$\mathrm{X} 1$ = saluran pemasaran

$\mathrm{X} 2$ = biaya pemasaran

$\mathrm{X} 3$ = volume penjualan

5. Pengujian Hipotesis

a) Uji Hipotesis Simultan ( Uji F ). Untuk menguji apakah semua variable indepnden atau bebas yang dimasukkan dalam model mempunyai pengaruh secara bersama - sama dimasukkan terhadap variable sependen atau terika ( Ghozali,20017). Pembuktiannya dilakukan dengan menggunakan uji $F$, yaitu membandingkan antara nilai $\mathrm{F}$ table $(\alpha=5 \%)$ dengan nilai $\mathrm{F}$ hitung. Apabila nilai $\mathrm{Ft}>\mathrm{Ft}$ dengan signifikan dibawah 0,05 (5\%), maka secara bersama-sama (simultan) variable bebas berpengaruh secara signifikan terhadap variable terikat dan sebalinya jika $\mathrm{Fh}<\mathrm{Ft}$, maka variable bebas tidak berpengaruh terhadap variable terikat.

b) Uji Hipoteis Parsial ( Uji t ). Untuk menunjukkan berapa jauh pengaruh satu variable independen/penjelas secara individu dalam menerapkan variasi variable dependen (Ghozali, 20017).Pembuktian dilakukan dengan uji t, yaitu dengan membandingkan antara nilai $\mathrm{t}$ hitung masing-masing variable bebas dengan $\mathrm{t}$ table( nilai kritis dengan tingkat signifikan $5 \%$ ). Jika t hitung variable bebas lebih besar dari t table dengan tingkat signifikan $<0,05$, maka variable indenpenden berpengaruh secara signifikan terhadap variable dependen.

c) Uji Determinan ( $\left.\mathrm{R}^{2}\right)$. Koefsien determinasi $\left(\mathrm{R}^{2}\right)$ pada itinya digunakan untuk mengukur seberapa jauh kemampuan model regreasi dalam menerapkan variasi dependen. Nilai koefisien determinansi adalah antara nol dan satu. Nilai $\mathbf{R}^{2}$ yang kecil berarti kemampuan variable-varoabel independen dalam menjelaskan variable dependen sangat terbatas. Nilai yang mendekati satu berarti variable-variabel indepnedn memebrikan hampir semua informasi yang dibutuhkan untuk memprediksi variable dependen. Variabel dependen dapat diketahui hasilnya setelah variable independen dengan nilai kuat dan tidak kuat.

\section{HASIL DAN PEMBAHASAN}

Kecamatan Tombolo Pao merupakan lokasi penelitian dengan jarak 56 kilometer dari pusat kota Makassar dengan jarak tempuh $35 \mathrm{~km} / \mathrm{jam}$ pada topografi adalah; sebelah selatan petbatasan Kabupaten Takalar, sebelah timur perbatasan Kabupaten Sinjai, Sebelah utara perbatasan Kahupaten Maros dan Bagian barat perbatasan Kecamatan Tinggi Moncong Kabupaten Gowa dengan ketinggian $1100 \mathrm{~m}$ dari ketinggian permukaan laut.

Geografis Kecamatan Tombolo Pao Kabupaten Gowa 11,56 Km2 dengan jumlah penduduk 14.734 jiwa, yang terdiri dari laki-laki 6.513 jiwa dan perempuan 8.218 jiwa. Potensi sektor perkebunan tanaman sayur - mayur di Desa Tombolo Pao adalah 2.752 ha dengan kapasitas produksi 18.005 ton setiap tahun dengan nilai penjualan mencapai 81,05 milyar rupian ( sumber; kantor statistik Dinas Tanaman Pangan dan Hortikultura Kabuapten Gowa 2019). Lokasi penelitian ini difokuskan pada Desa Kanreapia, dimana desa ini mempunyai penduduk 4.734 jiwa yang terdiri dari penduduk laki-laki 2.501 jiwa dan perempuan 2.233 jiwa. Jumkah penduduk desa ini mayoritas $(75 \%)$ petani sayu-mayur dan pada umumnya menanam kentang dan wortel dan tanaman lainnya, namun peneliti memilih buah kentang sebagai komoditas yang diteliti dengan alasan bahwa buah kentang adalah buah unggulan petani di Desa Kanreapia yang mempunyai kapasitas produksi mencapai rata-rata 12.000 ton/panen ( sumber: Dg.sewang; ketua kelompok tani ). Tujuan penelitian ini adalah untuk mengetahui bagaimana sistem distribusi pemasaran yang dilakukan petani kemtang hingga produksinya/buah kentang sampai ke konsumen akhir dengan berapa banyak pendapatan yang ditertima mealalui beberapa saluran pemasaran dengan kerjasama beberapa pedagang perantara. Adampun saluran pemasaran yang dilakukan petani kentang di Kecamatan Tombolo Pao hingga ke konsumen akhir dengan keterlibatan beberapa lembaga pemasaran/pedagang perantara adalah sebagai barikut :

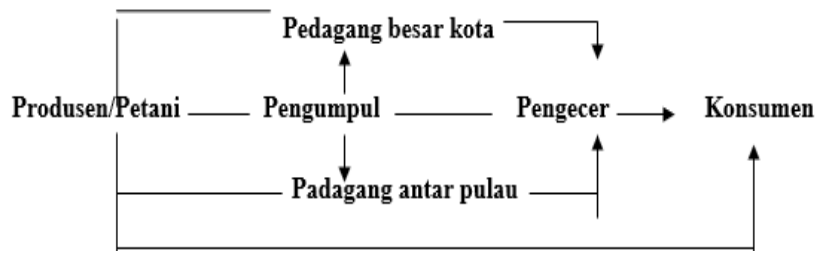

Gambar 4. Chennel Distribution of Marketing buah kentang di Kecamatan Tombolo Pao

Gambar 4 di atas memberikan gambaran bahwa tataniaga/distribusi pemasaran buah kentang dari petani hingga ke kosnumen akhir melalui beberapa saluran sehingga harga yang berlaku pada masing-masing lembaga pemasaran mempunyai tingkatan yang berbeda yang dipengaruhi oleh fungsi-fungasi pemasaran yang dilakukan.

\subsection{Deskripsi Karakteristik Responden}

Jumlah responden dalam penelitian ini sebanyak 143 orang petani yang semuanya merupakan petani kentang. Jumlah terebut dilakukan peneliti melakukan analisis berdasarkan komponen karakter. Maksud dilakukannya penganalisaan karakter terhadap responden ( 143 petani) adalah untuk mengetahui secara langsung kondisi pribadi petani sehingga mereka memilih untuk menekuni 
pekerjaan sebagai petani kentang walaupun tanaman lainnya yang sering dilakukan. Setelah peneliti melakukan observasi langsung ke beberapa dusun dan kebun kentang yang ada di Desa Kanreapia, telah ditemukan beberapa karakter petani antara lain; usia, jenis kelamin, tingkat pendidikan dan lamanya menekuni pekerjaan sebagai petani. Secara rinci dapat dijelaskan berdasarkan kondisi di lokasi penelitian adalah sebagai berikut:

Tabel 1. Karakteristik Responden Penelitian

\begin{tabular}{|c|c|c|c|}
\hline Karakteristik & Kategori & Frekuensi & Persentase \\
\hline \multirow{3}{*}{ Usia } & $<25$ Tahun & 47 & 32 \\
\hline & $26-40$ Tahun & 55 & 38 \\
\hline & 41-55 Tahun & 41 & 27 \\
\hline \multirow{3}{*}{ Jenis Kelamin } & $I^{\prime}$ & 73 & 51 \\
\hline & Lak1-lak1 & 70 & 31 \\
\hline & Perempuan & 70 & \\
\hline \multirow{3}{*}{$\begin{array}{c}\text { Pendidikan } \\
\text { Terakhir }\end{array}$} & SD/SLTP & 67 & 46 \\
\hline & SLTA & 61 & 42 \\
\hline & Sarjana & 15 & 11 \\
\hline \multirow{5}{*}{$\begin{array}{l}\text { Masa Kerja } \\
\text { Petani }\end{array}$} & $3 \mathrm{Th}$ & 7 & 0.05 \\
\hline & $4-7$ Tahun & 21 & 14 \\
\hline & 8-20 Tahun & 81 & 56 \\
\hline & 21-30 Tahun & 23 & 16 \\
\hline & $>\quad 30 \mathrm{Th}$ & 11 & 0,07 \\
\hline
\end{tabular}

Sumber : Data Primer Setelah Diolah. 2019

Berdasarkan Table 1 di atas memberikan gambaran bahawa responden/petani kentang yang berusia antara 2640 tahun mempunyai frekuensi atau tingkat persentase yang menekuni usaha tanaman kentang dan disusul usia yang 47 tahun dengan persentase $32 \%$. Untuk pendidikan petani telah didominasi petani yang tamat sekolah dasar dan tingkat pendidikan menengah dan lanjutan atas. Ini berarti bahwa petani yang menggantungkan hidupnya pada sektor tanaman kentang lebih banyak dipengaruhi oleh pengalaman bertani tanpa memperhatikan aspek pengembangan usaha. Dan bila dikatikan dengan masa kerja bertani kentang, dimana masa kerja petani antara 820 tahun yang mendominasi pekerjaan ini dan disusul oleh usia antara 21-30 tahun. Menurut Dg.Sewang selaku ketua kelompok tani kentang dan juga sebagai ketua masyarakat adat Kecamatan Tombolo Pao mengatakan bahwa petani yang ada di daerah ini khususnya di Desa Kanreapia merupakan petani yang turun temurun dari leluhrnya sehingga mereka betusaha bercocok tanam hortikultura khususnya tanaman kentang lebih banyak berdasarkan pengalaman, teramsuk aspek pemasaran.

Masa kerja responden cenderung bervariatif, hanya responden yang memiliki masa kerja jumlah terbanyak adalah usia 8 ( delapan ) tahun ke atas yang didominasi oleh pekerja laki-laki disbanding petani perempuan. Lanjut salah satu perempuan selaku petani kentang ibu Dg.Bani ( dusun Bontoa ) mengatakan bahwa, perempuan yang bekerja sebagai petani sayur-sayuran termasuk tanaman kentang baru mulai pada tahun 2009, dengan alasan bahwa mereka melakukan pekerjaan ini disebabkan oleh beberapa permasalahan antara lain; (1) permempuan dengan status janda ditinggal mati suami, (2) mempunyai area pertanian cukup luas, (3) suami mempunyai pekerja lain, (4) desakan ekonomi rumah tangga dan (5) permintaan pasar terhadap buah kentang makin meningkat.

\subsection{Pasca Panen dan Perkembangan Produksi Buah Kentang}

Agar kualitas produksi buah kentang tetap tinggi sehingga harga yang diterima oleh petani kentang tetap layak pula, maka perlakuan pasca panen merupakan hal yang sangat penting peranannya.Kecamatan Tombolo Pao pada Desa Kanreapia merupakan lokasi penelitian dengan alasan bahwa di desa ini merupakan sentra tanaman kentang dan buah kentang menjandi produk unggulan Kabupaten Gowa Sulawesi Selatan. Produksi buah kentang di Desa Tombolo Pao dalam kurun waktu lima tahun terakhir ini berdasarkan data dinas tanaman pangan Kabupaten Gowa adalah sebagai berikut:

Tabel 2. Perkembangan Ptoduksi Buah Kentang di Tombolo Pao (2015-2019)

\begin{tabular}{c|c|c|c}
\hline Tahun & $\begin{array}{c}\text { Volume } \\
\text { Produksi } \\
\text { ( Ton ) }\end{array}$ & $\begin{array}{c}\text { Nilai } \\
\text { Produksi } \\
\mathbf{( R p . 0 0 0 )}\end{array}$ & $\begin{array}{c}\text { Kenaikan/ } \\
\text { Turun } \\
(\%)\end{array}$ \\
\hline 2015 & $1.312,22$ & $9.185 .540,-$ & \\
2016 & $4.437,29$ & $31.061 .030,-$ & $33,82(+)$ \\
2017 & $2.679,62$ & $18.757 .340,-$ & $16,55(-)$ \\
2018 & $3.832,39$ & $26.826 .730,-$ & $14,30(+)$ \\
2019 & $4.103,43$ & $28.724 .010,-$ & $10,70(-)$ \\
\hline
\end{tabular}

Sumber: Kantor Dinas Tanaman Pangan dan Hortikultura Kabupaten Gowa-2019

Tabel 2 di atas memberikan gambaran bahwa perkembangan produksi buah kentang di Kabupaten Gowa di Desa Kanreaapia Kecamatan Tombolo Pao dari tahun 2015 sampai dengan tahun 2019 mengalami fluktuasi yang diakibatkan oleh cuaca dan harga faktor produksi ( pupuk,obat-obatan dan bibit) cenderung makin mahal sedangkan harga buah kentang kurang meningkat. Volume produksi pada table 3 di atas adalah akumulasi hasil panen dari tujuh dusu yang ada di Desa Kanreapia sebagai sentra tanaman kentang. Beberapa dusun yang ada di Desa Kanreapia yang setiap tahunnya menanam kentang dengan tingkat produksi yang dicapai dapat dilihat table berikut :

Tabel 3. Daftar Dusun Dan Produksi Buak Kentang Di Tombolo Pao Tahun 2019

\begin{tabular}{l|c|c|c}
\hline \multicolumn{1}{c|}{ Dusun } & $\begin{array}{c}\text { Volume } \\
\text { Produksi } \\
\text { ( Ton) }\end{array}$ & $\begin{array}{c}\text { Nilai Produksi } \\
\mathbf{( R p . 0 0 0 )}\end{array}$ & $\begin{array}{c}\text { Kenaikan } \\
\mathbf{( \% )}\end{array}$ \\
\hline Bontona & 187,46 & $1.312 .220,-$ & - \\
Bonto Lebang & 633,89 & $4.437 .230,-$ & 23,81 \\
Kanreapia & 382,80 & $2.769 .600,-$ & 17,75 \\
Hala Haliyah & 547,48 & $3.832 .360,-$ & 18,37 \\
Balang Lohe & 586,21 & $4.103 .470,-$ & 17,42 \\
Parang & 444,83 & $3.113 .810,-$ & 11,76 \\
Bandang & 511,55 & $3.580 .850,-$ & 2,87 \\
Silang Jaya & $3.294,22$ & $23.149 .540,-$ & 100,00 \\
Total & \multicolumn{3}{|c}{} \\
\hline \multicolumn{4}{l}{ Sumber; Kantor Dinas Tanaman Pangan Dan Hortikultura Kabupaten } \\
Gowa-2019
\end{tabular}


Tabel 3 di atas terlihat perkembangan produksi buah kentang setiap dusun di Desa Kanreapia dimana Dusun Bonto Lebang memproduksi buah kentang mencapai 633,89 ton atau 633.890 kilogram dengan nilai jual sebesar Rp.4,43 milyar dan disusul Dusun Balang Lohe sebanyak 586,21 ton dengan nilai jual mencapai Rp.4,10 milyar. Peningkatan kapasitas prouksi kedua dusun tersebut lebih tingggi dibanding dengan dusun lainnya karena lokasinya berada pada kaki gunung bawakaraeng dengan keadaan iklim sejuk dan dingin, sehingga walaupun terjadi musum kemarau/panas pasca panen tetap dilakukan dan prooduksi cenderungl meningkat atau petani tetap berhasil panen.

\subsection{Analisis Skala Usaha}

1. Skala Usala pada Saluran Pemasaran Pertama

Saluran pertama untuk pemasaran buah kentang oleh petani adalah salah satu pilihan petani untuk menjual hasil produksinya dengan mengeluarkan beberapa biaya. Biaya yang dikeluarkan petani dan diperhitungkan dari awal budidaya hingga biaya pemasaran dan kemudian terjadi transkasi penjualan kepada lembaga-lembaga pemasara yang terlibat dalam tataniaga komoditas tersebut. Adapun perhitungan biaya-biaya yang dikeluarkan petani dan penetapan harga jual untuk mendapatkan tingkat keuntungan dapat diuraikan pada table berikut:

Tabel 4. Biaya Produksi, Pemasaran dan Tingkat Penadapatan Pada Saluran I

(Petani-Pengumpul-Pengecer-Konsumen )

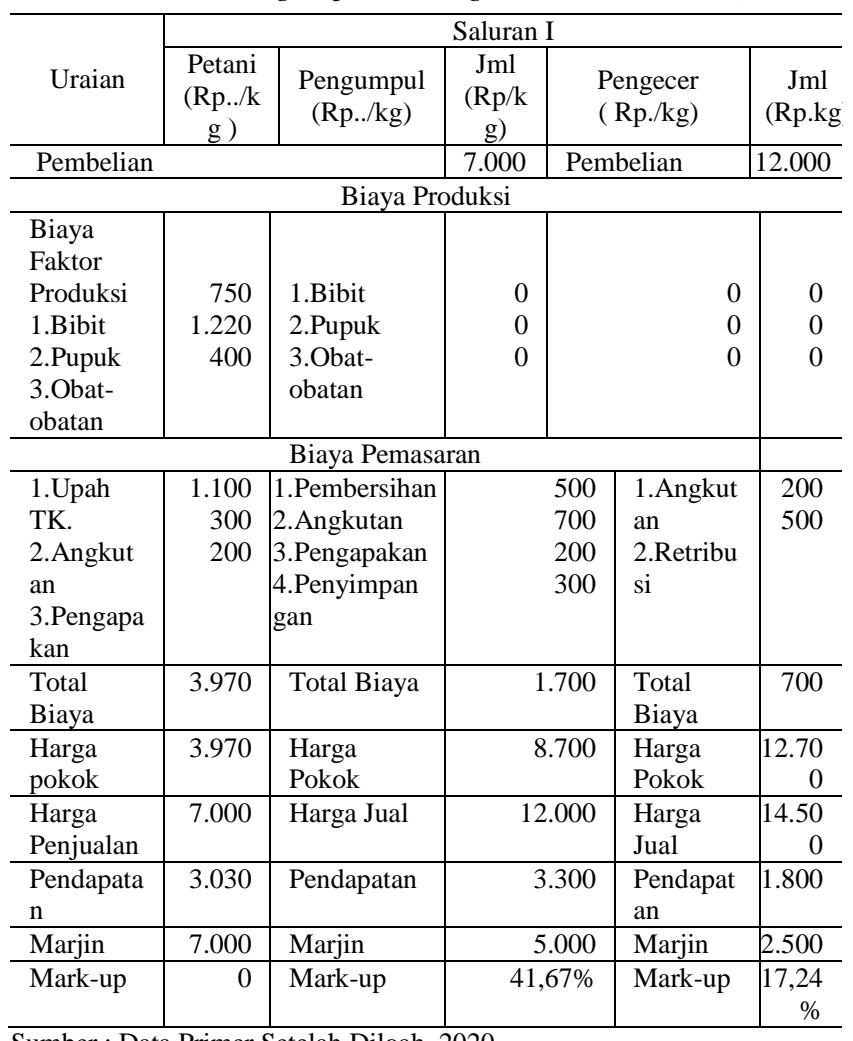

Sumber : Data Primer Setelah Diloah, 2020

Tabel 4 di atas memebrikan gambaran bahwa saluran I dalam pemasaran buah kentang dari petani melalui pedagang pengumpul kemudian lalu dijual ke pedagang pengecer sampai ke konsumen dengan harga yang diterima konsumen sebesar Rp.14.500. Sedangkan pendapatan yang paling banyak diterima pada saluran ini adalah pedagang pengumpul yang kedua adalah petani. Adanya perbedaan pendapatan yang diterima masing pelaku bisnis buah kentang disebabkan oleh fungsi-fungsi pemasaran dengan sejumlah biaya. Namun pihak petani telah mengeluarkan biaya terhadap faktor-faktor produksi ( pembelian bibit,pupuk dan obat-obatan) plus biaya pemasaran sehingga total biaya yang dikeluarkan lebih banyak dibandingkan dengan pedagang pengumpul dan pengecer. Sedangkan mark-up harga penjualan dari petani sampai ke konsuemn akhir adalah pedagang pengumpul ke padaang pengecer sebesar 41,67 \%, dengan pembelian dari petani Rp. $7.000 / \mathrm{kg}$, kemuadian dijual ke pedagang pengecer seharga Rp. $12.000 / \mathrm{kg}$, selanjutnya mark-up pedagang pengecer ke konsumen akhir sebesar 17,24\% dengan penjualan ke konsumen akhri seharga Rp.14.500/kg. Tingkat pendapatan yang diterima masingmasing pedagang perantana pada saluran ini dipengeruhi oleh aktivitas pemasaran dan harga penjualan yang berlaku. Danpak saluran ini kepada konsumen akhir adalah harga yang dibayarkan ke pedagang pengecer untuk pembelian buah kentang sebesar Rp. $14.500 / \mathrm{kg}$.

2. Skala Usaha Pada Saluran Pemasaran Kedua

Dalam pemsaran buah kentang pihak petani mempunyai beberapa alternative untuk memesarkan hasil taninya. Saluran kedua ini adalah salah satu pilihan petani untuk memasarkan hasil usahanya dengan mengeluarkan beberapa biaya. Biaya yang dikeluarkan petani dan diperhitungkan dari awal budidaya hingga biaya pemasaran dan kemudian terjadi transkasi penjualan kepada lembaga-lembaga pemasara atau pedagang perantara yang terlibat di dalamnya. Adapun perhitungan biaya-biaya yang dikeluarkan petani dan penetapan harga jual untuk mendapatkan tingkat keuntungan dapat diuraikan pada table berikut:

Tabel 5. Biaya Produksi, Pemasaran dan Tingkat Penadapatan Pada Saluran II

(Petani-Pedagang Besar-Pengecer-Konsumen)

\begin{tabular}{|c|c|c|c|c|c|}
\hline \multirow[b]{2}{*}{ Uraian } & \multicolumn{4}{|c|}{ Saluran II } & \multirow[b]{2}{*}{$\begin{array}{l}\text { Jumlah } \\
\text { (Rp/kg) }\end{array}$} \\
\hline & $\begin{array}{l}\text { Petani } \\
\text { (Rp./kg ) }\end{array}$ & $\begin{array}{c}\text { Pedagang } \\
\text { Besar } \\
\text { (Rp./kg) } \\
\end{array}$ & $\begin{array}{c}\text { Jumlah } \\
\text { (Rp/kg } \\
\text { ) }\end{array}$ & $\begin{array}{c}\text { Pengecer } \\
(\mathrm{Rp} / \mathrm{kg})\end{array}$ & \\
\hline & \multicolumn{2}{|c|}{ Pembelian } & 9.000 & Pembelian & 13.250 \\
\hline $\begin{array}{l}\text { Biaya Faktor } \\
\text { Produksi : } \\
\text { 1.Bibit } \\
\text { 2.Pupuk } \\
\text { 3.Obat- } \\
\text { obatan }\end{array}$ & $\begin{array}{r}750 \\
1.220 \\
400\end{array}$ & $\begin{array}{l}\text { 1.Angkutan } \\
\text { 2.Retribusi } \\
\text { 3.Obat- } \\
\text { obatan } \\
\end{array}$ & $\begin{array}{l}0 \\
0 \\
0\end{array}$ & $\begin{array}{l}\text { 1.Angkutan } \\
\text { 2.Retribusi } \\
\text { 3.Obatan }\end{array}$ & $\begin{array}{l}0 \\
0 \\
0\end{array}$ \\
\hline $\begin{array}{l}\text { 1.Upah TK. } \\
\text { 2.Angkutan } \\
\text { 3.Pengepakan }\end{array}$ & $\begin{array}{r}1.100 \\
300 \\
200\end{array}$ & $\begin{array}{l}\text { 1.Pembersihan } \\
\text { 2.Angkutan } \\
\text { 3.Pengapakan } \\
\text { 4.Penyimpan } \\
\text { gan }\end{array}$ & $\begin{array}{l}500 \\
800 \\
300 \\
400\end{array}$ & $\begin{array}{l}\text { 1.Angkutan } \\
\text { 2.Retribusi }\end{array}$ & $\begin{array}{l}200 \\
500\end{array}$ \\
\hline Total Biaya & 3.970 & Total Biaya & 2.000 & Total Biaya & 700 \\
\hline Harga pokok & 3.970 & Harga Pokok & 11.000 & Hrg.Pokok & 13.250 \\
\hline $\begin{array}{l}\text { Harga } \\
\text { Penjualan }\end{array}$ & 9.000 & Harga Jual & 13.250 & Hrg. Jual & 14.500 \\
\hline Pendapatan & 5.030 & Pendapatan & 2.250 & Pendapatan & 1.250 \\
\hline Marjin & 9.000 & Marjin & 4.250 & Marjin & 1.950 \\
\hline
\end{tabular}




\begin{tabular}{l|r|l|l|l|l}
\hline Mark-up & 0 & Mark-up & $16,98 \%$ & Mark-up & $13,45 \%$ \\
\hline \multicolumn{5}{l}{ Sumber : Data Primer Setelah Diloah, 2020}
\end{tabular}

Tabel 5 di atas memebrikan gambaran tentang aktivitas-aktivitas pemasaran yang dilakukan oleh pedagang besar di kota baik pedagang antar daerah maupun pedagang besar di kecamatan Tombolo Pao dan Tinggi Maoncong Kabupaten Gowa. Fungsi pemasaran yang dilakukan pedagang besar tersebut meliputi; pembersihan/sortiran, pengangkutan, pengepakan dan penyimpanan buah kentang di alat pendingin/frischer agar kentang tetap segar dan telah mengeluarkan biaya sebesar Rp.2.000/kg, sedangkan pihak petani mengeluarkan biaya sebesar Rp.3.970/kg ( teramsuk biaya faktor produksi). Untuk perolehan pendapatan pihak petani sebesar Rp.5.030 dan pendapatan pihak pedagang sebesar sebesar Rp.2.250 dan lebih banyak petani yang disebabkan oleh harga penjualan yang diperlakukan ke pedagang besar lebih tinggi dibanding harga yang diperlakukan kepada pedagang pengumpul saluran pertama di atas dengan alasan petani bahwa pedagang besar ini melakukan sortiran sehingga ada buah kentang yang kecil dan kualitasnya rendah mereka tidak membeli, maka secara langsung mengurangi bobot timbangan padahal yang dijual adalah berat timbangan buah kentang. Danpak saluran ini kepada konsumen akhir adalah harga yang dibayarkan ke pedagang besar untuk pembelian buah kentang sebesar Rp. 13.250/kg.

3. Skala Usaha Pada Saluran Pemasaran Ketiga

Seperti alasan yang dikemukakan pada saluran sebelumnya bahwa ada beberapa alternative petani yang dilakukan untuk memasarkan hasil taninya dalam hal ini buah kentang. Saluran ketiga ini adalah dari petani pedagang antar pulau - pengecer hingga ke konsumen akhir. Aktivitas - aktivitas yang dilakukan setiap lembaga pemasaran/pedagang perantara masing-masing lain tergantung strategi pemasaran yang dilakukan. Untuk petani, aktivitas yang dilakukan untuk mendapatkan hasil usaha taninya terdiri dari dua kegiatan antara lain aspek produksi meliputi; pengadaan bibit, pemupukan dan obatobatan, sedangkan aspek pemasaran meliputi kegiatan; upah tenaga kerja, angkutan dan pengepakan. Kedua aspek yang dilakukan petani tersebut telah mengeluarkan total biaya sebesar Rp.3.970/kg dengan asumsi bahwa biaya tersebut beralaku pada saat peneliti melakukan penelitian ( biaya dapat berubah sesuai perkembangan pasar). Pada Saluran, perlakuan fungsi-fungsi pemasaran dan aktivitas yang dilakukan setiap lembaga pemasaran/pedagang perantara uraiannya dapat dilihat pada table berikut :

Tabel 6. Biaya Produksi, Pemasaran dan Tingkat Penadapatan Pada Saluran III

(Petani-Pengumpul-Pedagang Besar Antar PulauPengecer - Konsumen )

\begin{tabular}{|c|c|c|c|c|c|c|c|}
\hline \multirow[b]{2}{*}{$\begin{array}{l}\text { Urai } \\
\text { an }\end{array}$} & \multicolumn{7}{|c|}{ Saluran III } \\
\hline & $\begin{array}{c}\text { Petani } \\
\text { (Rp../ } \\
\text { kg ) }\end{array}$ & $\begin{array}{c}\text { Pengumpul } \\
\text { (Rp../kg) }\end{array}$ & $\begin{array}{c}\mathrm{ml}(\mathrm{Rp} \\
)\end{array}$ & $\begin{array}{l}\text { Ped. } \\
\text { Besar } \\
\text { Antar } \\
\text { Pulau }\end{array}$ & $\begin{array}{l}\text { Jml } \\
(\mathrm{Rp})\end{array}$ & $\begin{array}{l}\text { Penge } \\
\text { cer } \\
\text { (Rp./kg) }\end{array}$ & $\begin{array}{l}\mathrm{Jml}(\mathrm{R} \\
\mathrm{p} / \mathrm{kg})\end{array}$ \\
\hline
\end{tabular}

\begin{tabular}{|c|c|c|c|c|c|c|c|}
\hline & & & & Rp../kg) & & & \\
\hline Pembeliar & & & 7.000 & Pembelian & 12.000 & $\begin{array}{l}\text { Pembe } \\
\text { lian }\end{array}$ & 15.500 \\
\hline \multicolumn{8}{|c|}{ Biaya Produksi } \\
\hline $\begin{array}{l}\text { Biaya } \\
\text { Faktor } \\
\text { Produks } \\
\text { i : } \\
\text { 1.Bibit } \\
\text { 2.Pupuk } \\
\text { 3.Obata } \\
\text { n } \\
\end{array}$ & $\begin{array}{r}750 \\
1.220 \\
400\end{array}$ & $\begin{array}{l}\text { 1.Binit } \\
\text { 2.Pupuk } \\
\text { 3.Obata } \\
\mathrm{n}\end{array}$ & $\begin{array}{l}0 \\
0 \\
0\end{array}$ & $\begin{array}{l}\text { 1.Binit } \\
\text { 2.Pupu } \\
\mathrm{k} \\
\text { 3.Obat } \\
\text { an }\end{array}$ & $\begin{array}{l}0 \\
0 \\
0\end{array}$ & $\begin{array}{l}\text { 1.Binit } \\
\text { 2.Pupu } \\
\mathrm{k} \\
\text { 3.Obat } \\
\text { an }\end{array}$ & $\begin{array}{l}0 \\
0 \\
0\end{array}$ \\
\hline \multicolumn{8}{|c|}{ Biaya Pemasaran } \\
\hline $\begin{array}{l}\text { 1.Upah } \\
\text { TK. } \\
\text { 2.Angk } \\
\text { utan } \\
\text { 3.Ngapa } \\
\text { k }\end{array}$ & $\begin{array}{r}1.100 \\
300 \\
200\end{array}$ & $\begin{array}{l}\text { 1.Pembe } \\
\text { rsih } \\
\text { 2.Angku } \\
\text { tan } \\
\text { 3.Ngapa } \\
\text { k } \\
\text { 4.Simpa } \\
\text { ng }\end{array}$ & $\begin{array}{l}500 \\
700 \\
200 \\
300\end{array}$ & $\begin{array}{l}\text { 1.Bers } \\
\text { ihan } \\
\text { 2.Ang } \\
\text { kutan } \\
\text { 3.Nga } \\
\text { pak } \\
\text { 4.Sim } \\
\text { pang }\end{array}$ & $\begin{array}{l}500 \\
800 \\
300 \\
400\end{array}$ & $\begin{array}{l}\text { 1.Ang } \\
\text { kutan } \\
2 . \text { Retri } \\
\text { busi }\end{array}$ & $\begin{array}{l}200 \\
500\end{array}$ \\
\hline $\begin{array}{l}\text { Total } \\
\text { Biaya }\end{array}$ & 3.970 & $\begin{array}{l}\text { Total } \\
\text { Biaya }\end{array}$ & 1.700 & $\begin{array}{l}\text { Total } \\
\text { Biaya }\end{array}$ & 2.000 & $\begin{array}{l}\text { Total } \\
\text { Biaya }\end{array}$ & 700 \\
\hline $\begin{array}{l}\text { Harga } \\
\text { pokok }\end{array}$ & 3.970 & $\begin{array}{l}\text { Harga } \\
\text { Pokok }\end{array}$ & 8.700 & $\begin{array}{l}\text { Hrg.P } \\
\text { okok }\end{array}$ & 14.000 & $\begin{array}{l}\text { Hrg.P } \\
\text { okok }\end{array}$ & 16.200 \\
\hline $\begin{array}{l}\text { Harga } \\
\text { Jual }\end{array}$ & 7.000 & $\begin{array}{l}\text { Harga } \\
\text { Jual }\end{array}$ & $\begin{array}{c}12.00 \\
0\end{array}$ & $\begin{array}{l}\text { Hrg.Ju } \\
\text { al }\end{array}$ & 16.250 & $\begin{array}{l}\text { Hrg.Ju } \\
\text { al }\end{array}$ & 17.450 \\
\hline $\begin{array}{l}\text { Pendapa } \\
\tan \end{array}$ & 3.030 & $\begin{array}{l}\text { Pendapa } \\
\tan \end{array}$ & 3.300 & $\begin{array}{l}\text { Penda } \\
\text { patan }\end{array}$ & 2.250 & $\begin{array}{l}\text { Penda } \\
\text { patan }\end{array}$ & 1.250 \\
\hline Marjin & 7.000 & Marjin & 5.000 & Marjin & 4.250 & Marjin & 1.950 \\
\hline $\begin{array}{l}\text { Mark- } \\
\text { up }\end{array}$ & 0 & Mark-up & $\begin{array}{c}41,67 \\
\%\end{array}$ & $\begin{array}{l}\text { Mark- } \\
\text { up }\end{array}$ & $\begin{array}{r}13,84 \\
\%\end{array}$ & $\begin{array}{l}\text { Mark- } \\
\text { up }\end{array}$ & $7,16 \%$ \\
\hline
\end{tabular}

Tabel 6 di atas telah diuraikan tentang struktur alur pemasaran buah kentang yang melibatkan beberapa lembaga pemasaran yang biasa disebut pedagnag perantar yang ikut serta dalam penyampaian barang/buah kentang dari produsen/petani hingga ke konsumen akhir. Tabel tersebut di atas memberikan gambaran bahwa tingkat pendapatan yang diterima petani lebih rendah dibanding dengan pedagang pengumpul karena harga penjualan yang diterima petani lebih rendah dibanding harga jual pedagang pengumpul ke pedagang besar di kota khususnya di Makassar sebagai tujuan pemasaran utama buah kentang. Secara hitungan, harga jual petani ke pedagang pengumpul sebesar Rp..7.000/kg sedangkan harga jual pengumpul ke pedagang besar sebesar Rp.12.000/kg atau di mark-up 41,67\%. Kemudian pihak pedagang besar menjual kepada pedagang pengecer sebesar Rp.16.250/kg dan atau mark-up harga sebasar $13,84 \%$. Adanya perbedaan harga jual masing-masing pedagang perantara pada saluran ini disebabkan adanya kegiatan fungsi-fungsi pemasaran dan tingkat pendapatan yang diinginkan. Begitu pula pada saluran keempat berikut ini:

4. Skala Usaha Pada Saluran Pemasaran Keempat

Saluran keempat ini melibattkan dua lembaga pemasaran atau pedagang perantar sampai ke konsumen akhir. Pedagang perantara yang dimaksud adalah pedagang besar antar pulau kemudian dipasarkan ke pengercer. Menurut salah satu pedagang besar antar pulau yang ditemui di Kacematan Tombolo Pao yakni Bapak M.Yafzil mengatakan bahwa pembelian buah kentang dari petani lebih tinggi dibanding pembelian dari pengumpul karena tidak semua buah kentang yang ditawarkan petani dibeli melainkan dilakukan sortiran sehingga banyak buah kentang tidak masuk kualitas 
standar. Pedagang besar antar pulau dalam melakukan pemasaran antar pulau biasanya melalui Kota Pare-Pare dengan tujuan Kalimantan yang langsung membeli ke petani di Kecamatan Tombolo Pao dengan harga yang lebih tinggi dibanding dengan pedagang perantara lainnya. Sistem pembelian yang dilakukan padagang besar ini adalah lebih awal melakukan kontrak dengan kelompok tani dan biasanya membayar duluan tanpa buah kentang.

Pedagang besar antar pulau ini dalam melakukan pembelian buah kentang dengan jumlah cukup banyak dan rata-rata 6 ton setiap angkutan dengan tujuan Makassar dengan kota Pare-Pare untuk tujuan Ke Kalimantan.Untuk lebih jelasnya diuraikan pada table berikut :

Tabel 7. Biaya Produksi, Pemasaran dan Tingkat Penadapatan Pada Saluran IV

(Petani - Pedagang Besar Antar Pulau - Pengecer Konsumen )

\begin{tabular}{|c|c|c|c|c|c|}
\hline \multirow{2}{*}{ Uraian } & \multicolumn{4}{|c|}{ Saluran II } & \multirow[b]{2}{*}{$\begin{array}{c}\mathrm{Jml} \\
(\mathrm{Rp} / \mathrm{k} \\
\mathrm{g})\end{array}$} \\
\hline & $\begin{array}{c}\text { Petani } \\
\text { (Rp./k } \\
\text { g ) }\end{array}$ & $\begin{array}{c}\text { Pedagang } \\
\text { Besar Antar } \\
\text { Pulau } \\
\text { (Rp./kg) }\end{array}$ & $\begin{array}{c}\mathrm{Jml} \\
(\mathrm{Rp} / \mathrm{k} \\
\mathrm{g})\end{array}$ & $\begin{array}{l}\text { Pengecer } \\
(\mathrm{Rp} / \mathrm{kg})\end{array}$ & \\
\hline & & Pembelian & 11,000 & $\begin{array}{l}\text { Pembelia } \\
\mathrm{n}\end{array}$ & 17.250 \\
\hline $\begin{array}{l}\text { Biaya } \\
\text { Faktor } \\
\text { Produksi : } \\
\text { 1.Bibit } \\
\text { 2.Pupuk } \\
\text { 3.Obat- } \\
\text { obatan }\end{array}$ & $\begin{array}{r}750 \\
1.220 \\
400\end{array}$ & $\begin{array}{l}\text { 1.Bibit } \\
\text { 2.Pupuk } \\
\text { 3.Obat-obatan }\end{array}$ & $\begin{array}{l}0 \\
0 \\
0\end{array}$ & $\begin{array}{l}\text { 1.Bibit } \\
\text { 2.Pupuk } \\
\text { 3.Obatan }\end{array}$ & $\begin{array}{l}0 \\
0 \\
0\end{array}$ \\
\hline $\begin{array}{l}\text { 1.Upah TK. } \\
\text { 2.Angkutan } \\
\text { 3.Pengepak } \\
\text { an }\end{array}$ & $\begin{array}{r}1.100 \\
300 \\
200\end{array}$ & $\begin{array}{l}\text { 1.Sortir- } \\
\text { bersih } \\
\text { 2.Angkutan } \\
\text { 3.Pengapakan } \\
\text { 4.Penyimpan } \\
\text { gan }\end{array}$ & $\begin{array}{l}400 \\
800 \\
500 \\
300\end{array}$ & $\begin{array}{l}\text { 1.Angkut } \\
\text { an } \\
\text { 2.Retribu } \\
\text { si } \\
\text { 3.Upah Tk }\end{array}$ & $\begin{array}{l}200 \\
500 \\
300\end{array}$ \\
\hline Total Biaya & 3.970 & Total Biaya & 2.000 & $\begin{array}{l}\text { Total } \\
\text { Biaya }\end{array}$ & 1.000 \\
\hline $\begin{array}{l}\text { Harga } \\
\text { pokok }\end{array}$ & 3.970 & Harga Pokok & 13.000 & $\begin{array}{l}\text { Hrg.Poko } \\
\text { k }\end{array}$ & 18.250 \\
\hline $\begin{array}{l}\text { Harga } \\
\text { Penjualan }\end{array}$ & 11.000 & Harga Jual & 17.250 & Hrg. Jual & 21.000 \\
\hline Pendapatan & 7.030 & Pendapatan & 4.250 & $\begin{array}{l}\text { Pendapat } \\
\text { an }\end{array}$ & 2.750 \\
\hline Marjin & 11.000 & Marjin & 6.250 & Marjin & 3.750 \\
\hline Mark-up & 0 & Mark-up & $36,23 \%$ & Mark-up & $17,85 \%$ \\
\hline
\end{tabular}

Pada Table 7 di atas memberikan gambaran bahwa pemasaran melalui saluran keempat ini pihak petani mendapatkan keuntungan lebih besar dibanding melalui saluran lain. Namun volume penjualan melalui saluran ini dari segi kuantitas lebih rendah dibanding dengan pembelian dari pedagang perantara lainnya. Secara hitungan pada table di atas, dimana harga penjualan petani ke pedagang besar antar pulau sebesar Rp. 11.000 $/ \mathrm{kg}$, dan harga pokok buah ketang sebesar Rp.3.970/kg sehingga pendapatan bersih yang diterima petani sebesar Rp. 7.030 dan atau 56,47 \% dari harga pokok. Sedangkan pihak pedagang antar pulau ke daerah ( Katim dan NTT ) melalui pelabuhan Pare-Pare dengan jual Rp.17.250/kg dan pendapatan yang diterima sebesar Rp.4.250/kg dan atau mark-up sebesar $36,23 \%$. Selanjutnya, pedagang pengecer menjualnya ke konsumen di daerah tujuan dengan harga rata-rata sebesar Rp.21.000/kg dan atau di mark-up sebesar $17,85 \%$.

5. Skala Usaha Pada Saluran Pemasaran Kelima

Skala usaha petani melalui saluran ini cukup cepat perputarannya, namun volume penjualan terbatas karena kemampuan pengecer untuk membeli buah kentang lebih banyak terbatas modal usaha yang dimiliki. Tipe saluran ini adalah urutan kedua dari saluran terpendek untuk langsung ke konsumen akjhir dengan harga yang relative rendah dibanding harga yang diperlakukan pada pedagang perantara. Salah seorang responden ibu Dg.Bani selaku petani kentang yang cukup lama ( sejak tahun 1988) menekuni pekerjaan ini mengatakan bahwa harga jual pengecer rata-rata Rp.6.500/kg dan atau 3,12\% dibawa harga ke pedagang perantar/lembaga pemasaran. Alasannya adalah konsumen yang langsung ke petani sekedar untuk kebutuhan konsumsi dan oleh-oleh untuk keluarga, dan biasanya pengujung rekreasi ke Malino. Untuk jelasnya, diuraikan dalam table berikut :

Tabel 8. Biaya Produksi, Pemasaran \& Tingkat Penadapatan Pada Saluran V

(Petani-Pengecer - Konsumen )

\begin{tabular}{|c|c|c|c|c|}
\hline \multirow[b]{2}{*}{ Uraian } & $\begin{array}{l}\text { Petani } \\
(\mathrm{Rp} . . / \mathrm{kg}\end{array}$ & \multicolumn{2}{|c|}{$\begin{array}{c}\text { Pedagang Pengecer } \\
(\mathrm{Rp} . . / \mathrm{kg})\end{array}$} & \multirow[t]{2}{*}{$\begin{array}{l}\text { Jumlah } \\
\text { (Rp/kg) }\end{array}$} \\
\hline & & & & \\
\hline & & \multicolumn{2}{|r|}{ Pembelian } & 6.500 \\
\hline \multicolumn{5}{|c|}{$\begin{array}{ll}\text { Biaya } & \text { Faktor }\end{array}$} \\
\hline \multicolumn{5}{|c|}{ Produksi : } \\
\hline \multicolumn{2}{|l|}{ 1.Bibit } & 750 & 1.Bibit & 0 \\
\hline \multicolumn{2}{|l|}{ 2.Pupuk } & 1.220 & 2.Pupuk & 0 \\
\hline \multicolumn{2}{|c|}{ 3.Obat-obatan } & 400 & 3.Obat-obatan & 0 \\
\hline \multicolumn{2}{|c|}{ 1.Upah TK. } & 1.100 & 1.Angkutan & 200 \\
\hline \multicolumn{2}{|c|}{ 2.Angkutan } & 300 & 2.Retribusi & 300 \\
\hline \multicolumn{2}{|c|}{ 3.Pengepakan } & 200 & & \\
\hline \multicolumn{2}{|c|}{ Total Biaya } & 3.970 & Total Biaya & 500 \\
\hline \multicolumn{2}{|c|}{ Harga pokok } & 3.970 & Harga Pokok & 7.000 \\
\hline \multicolumn{2}{|c|}{ Harga Penjualan } & 6.500 & Harga Jual & 11.000 \\
\hline \multicolumn{2}{|c|}{ Pendapatan } & 2.530 & Pendapatan & 4.000 \\
\hline \multicolumn{2}{|l|}{ Marjin } & 6.500 & Marjin & 4.500 \\
\hline \multicolumn{2}{|l|}{ Mark-up } & 0 & Mark-up & $36,12 \%$ \\
\hline
\end{tabular}

Tabel 8 di atas adalah data primer setelah diolah, telah diperoleh suatu hasil analisis secara perhitungan yakni perbandingan tingkat pendapatan petani dan pengecer untuk pemasaran buah kentang hingga ke konsumen akhi. Melalui saluran ini, petani mendapatkan keuntungan sebesar Rp.2.530/kg sedangkan pihak pengecer memperoleh keuntungan sebesar Rp. 4.000/kg. Adanya perbedaan keuntungan antara petani dan pengecer pada saluran ini disebabkan oleh biaya pemasaran yang dikelarkan masing-masing. Baiya yang dikeluarkan petani sebesar Rp.3.970/kg dan pihak pengecer hanya mengeluarka biaya pemasaran sebesar Rp.500/kg sehingga tingkat pendapatan lebih tinggi pengecer dan atau mark-up sebesar 36,12\%. Dalam saluran ini, petani dalam menetapkan harga pokok produksi dipengaruhi 
oleh dua aspek yaitu biaya produksi dan biaya pemasaran, sehingan harga pokonya lebih tinggi dibanding lembaga pemasaran/pedagang perantara lainnya. Menurut ahli makro ekonomi ( Coub Doglas-1979) mengatakan bahwa dalam perhitungan harga pokok produksi hasil pertanian ( agricultura) ada tiga faktor yang harus diperhitungan yakni; tenaga keraj, luas lahan dan bibit.

6. Skala Usaha Pada Saluran Pemasaran Keenam (Petani - Konsumen)

Untuk menjelaskan skala usaha pada saluran ini telah dideskripsikan secara deskriptif tentang total biaya yang dikeluarkan petani dan tingkat pendapatan yang diperoleh atas transaksi dengan konsumen akhir. Perlakuan harga kepada konsumen lebih rendah dibanding dengan penjualan kepada pedagang perantara dengan alasan bahwa konsumen yang membeli buah kentang yang langsung ke Desa Kanreapian pada umumnya pengunjung rekreasi wisata ke Malino untuk wisata alam. Adapun harga jual yang diperlakukan kepada konsumen yang langsung ke petani di Desa Kanreapia dengan harga antara Rp.14.500/kg-Rp.15.500/kg tergantung kualitas buah kentang. Tingkat keuntungan yang diperoleh petani bila dijual secara langsung ke konsumen adalah Rp.11.030/kg dan atau lebih mahal harga penjulannya dibanding ke pedagang perantara yang terlibat dalam perdagangan komodity ini.1Menurut Downey dan Erickson ( 1989 ), menyatakan bahwa tingkat efisiensi pemasaran buah hortikultura adalah pemasaran yang mempunyai saluran pendek dan barang cepat sampai ke konsumen akhir. Alasan Downey dkk tentang komoditas hasil pertanian bahwa pada umumnya buah hortikultura tidak bias bertahan lama dan paling lama 1-3 hari.

\subsection{Analisis Efisiensi Usaha}

Efisiensi usaha pada dasarnya adalah ratio luaran terhadap masukan baik biaya produksi maupun biayabiaya yang dikeluarkan untuk memasarkan barang dan jasa. Dalam penelitian ini, peneliti mengkaji tentang efisiensi pemasaran yang dilakukan petani terhadap saluran distribusi buah kentang sampai ke konsumen akhir. Khotler (1998) mengatakan bahwa luaran pemasaran adalah hasil penjualan terakhir yang diterima sedangkan masukan pemasaran merupakan dana yang dikelola untuk memperoses dan mengangkut produk sehingga tiba ke tangan konsumen.

Efisiensi saluran distribusi pemasaran ( channel distributiona of marketing) komodity buah kentang dari Kecanatan Tombolo Pao Kabupaten Gowa sebagai daerah produsen dan Kota Makassar sebagai daerah konsumen, maka berikut ini diuraikan tingkat efisiensi saluran pemasaran berdasarkan rumus efisiensi pemasaran yaitu biaya pemasaran dibagi dengan nilai produk yang dipasarkan sebagai berikut :

Tabel 9. Efisiensi dan Keuntungan Channel Distribution Of Marketing Buah Kentang dari Kecamatan Tombolo Pao ke Kota Makassar

\begin{tabular}{c|c|c|c}
\hline $\mathrm{p}$ & Channel Distriutin & Efisiency (\%) & Profit $(\mathrm{Rp} / \mathrm{Kg})$ \\
\hline 1 & Pertama & 11,94 & 8.130
\end{tabular}

\begin{tabular}{c|c|c|c}
2 & Kedua & 10,70 & 8.530 \\
3 & Ketiga & 13,85 & 9.300 \\
4 & Keempat & 21,39 & 14.00 \\
5 & Kelima & 12,00 & 6.505 \\
6 & Keenam & 9,09 & 11.030 \\
\hline \multicolumn{2}{|l}{ Sumber : Data Primer Setelah Diloah, 2020}
\end{tabular}

Tabel 9 di atas adalah hasil pengolahan data primer pada table pertama hingga tabel 9 dengan analisis efisiensis usaha pada formulasi total biaya dibagi dengan nilai jual produ dan dikalikan dengan !00\%. Berdasarkan hasil hitung efisiensi usaha pada buah kentan yang diuraikan pada table di atas, maka saluran yang palin efisien adalah yang keenam (petani-konsumen). Efisensi usaha atau pemasaran suatu produk yang dalam hal ini buah kentang dari Kecamatan Tombolo Pao Kabupaten Gowa sebagai wilayah produsen dan ke Kota Makassar sebagai wilayah pemasaran, bila dilihat urain pada table diatas ternyata yang paling tinggi memberikan profit usaha adalah pada saluran keempat. Menurut Ketua Kelompok Tani hortikultura Di Desa Kanreaapia bapak Dg. Baso.menyatakan bahwa harga buah kemtang yang paling tinggi harga jualnya adalah langsung ke konsumen akhir. Namun volume penjualan sangat terbatas karena biasanya konsumen seperti ini lebih banyak pengunjung ke Wisata Malino sambil membeli buah kentang untuk konsumsi rumah tangga dan oleh-oleh keluaragan dan tetangga.

\section{KESIMPULAN DAN SARAN}

Hasil penelitian menyimpulkan bahwa pengujian hipotesis pertama yang dilakukan membuktikan bahwa ada pengaruh yang positif variable saluran pemasaran (X1) dengan tingkat pendapatan petania dengan koefisien 0,586 . Hasil penelitian ini menunjukkan adanya hubungan signifikan antara saluran pemasaran dengan pendapatan petani. Pengujian hipotesis kedua menunjukkan bahwa variable biaya pemasaran (X2) kurang berpengaruh terhada tingkat pendapatan petani. Alasannya adalah nilai signifikan 0,158 lebih besar daripada 0,05 . Ini berarti bahwa petani perlu memahami pengeluaran biaya pemasaran tidak berpengaruh terhadap tingkat pendapatan petani. Pengujian hipoteis ketiga ini yakni volume penjualan yang merupakan variable ketiga berpengaruh positif dKomitmen organisasi sebagai variable indepnden (X3) dengan nilai signifikan terhadap pendapatan petani dengan koefisie sebesar 0,249 . Berarti nilai tersebut lebih besara daripada 0,05

\section{DAFTAR PUSTAKA}

Cliving, Gurcik (2004), dan Anto, 2000. Metodologi Penelitian. Penerbit Erlangga. Jakarta.

Collier, David A., 2003, A New Marketing Mix. Stresses Service, The Journal of Business Strategy.

Engel, James. F, Roger D. Blackwell, dan Paul W. Minniard, 2004, perilaku Konsumen, Edisi Keenam, Jilid Satu, Binarupa Aksara, Jakarta. 
Husein umar, 2007, Riset Pemasaran dan Peritaku Konsumen PT. Gramedia Pustaka Utama, Jakarta.

J. Supranto, 2001 , Pengukuran Tingkat Kepuasan Pelanggan, Untuk Menaikkan Pangsa Pasar, Penerbit Rineka Cipta, Jakarta.

Kamarudin, 2003. Faktor stmulus Pemasaran, Faktor Lingkungan, dan Fakor lndividu Yang Mempengaruhi Preferensi Masyarakat Terhadap Bank Syariah di Wilayah Samarinda. Tesis. Samarinda.

Kotler, Philip. 2005. Manajemen Pemasaran. Edisi 11. Jilid 1 dan 2. Penerbit PT INDEKS Kelompok Gramedia.

lrawan D., Handi. 2003. Indonesian Customer Satisfaction. Penerbit PT Elex Media Komputindo. Jakarta.

Nonci, Nurjannah, Nurmi Nonci, Harifuddin Halim, Muliani. 2019. Role of Supply Chain in Cocoa Blue Print Model Performance in National Development Program. International Journal of Supply Chain Management. Vol. 8 No. 6 (2019), pp. 198-210.

Oparilova, Adrian, 2003, The Essence of servive Marketing, prentive Hall International, United Kingdom.

Reny, A. R., Saleh, M. Y., \& Sapiri, M. (2019). Pengaruh Return On Asset Dan Tobin's Q Terhadap Volume Perdagangan Saham Pada Perusahaan Perbankan Yang Listing Di Bursa Efek Indonesia Periode Tahun 2013-2017. Indonesian Journal of Business and Management, 1(2), 09-16. https://doi.org/10.35965/jbm.v1i2.294

Sanyoto, 2002. Faktor-Faftor Yang Mempengaruhi Perilaku Konsumen Untuk Menabung Pada Bank Perkreditan Rakyat (BPR) di Makassar. Tesis Makassar.

Simamora, Bilson. 2004. Panduan Riset Perilaku Konsumen. Cetakan 2. Penerbit PT Gramedia pustaka Utama. Jakarta.

Singarimbun, Masri dan sofian Effendi, 2006, Metode penelitian survey, PT. Pustaka LP3ES, Jakarta. .

Smith, P. R, 2004, Jawaban Jitu untuk Berbagai pertanyaan pemasaran yang sulit Alih Bahasa, Endi Achmadi, penerbit Erlangga, Jakarta.

Subowo, 2001. Faktor-Faktor Yang Mempengaruhi Keputusan Nasabah Memiliki Kartu Plus Pada BNI Cabang Semarang. Tesis. Makassar

Sugiyono, 2007. Metode Penelitian Bisnis. Cetakan 10. Penerbit Alfabeta, CV.Bandung

Suharsimir Arikunto. 2006. Prosedur Penelitian, Rineka cipta. Jogjakarta.

Wiji Suratno. 2003. Pengaruh Kualitas Kredit, Kepuasan pelanggan Dan Kualitas Pelayanan Terhadap Kinerja perbankan. Tesis. Makassar

Zylstra (20020 Riset Bisnis. Edisi 1. Cetakan 1. Penerbit Graha llmu. Yogyakarta. 